His Excellency Muhammed Hosni Mubarak

President of the Arab Republic of Egypt

Cairo

Egypt

Dear Mr. President:

I write with urgency to request your attention to a matter of great concern to many scholars and writers.

Members of this Association and scholars everywhere are saddened to learn of the recent imprisonment of Nowal Sadawi. Ms. Sadawi is widely esteemed for her important and inspiring work. Her spirit has enhanced the causes of freedom and progress in our time. We believe that her release from prison would have a similar effect and ardently solicit your personal attention to this plea.

With great respect, I am

Yours sincerely,

Richard Sklar

In the Case of "Bantustans," the western Sahara and maps:

\title{
Dear Sir:
}

The Board of Directors of the African Studies Association has noted that major publishers of maps are misrepresenting two situations in Africa.

First, a few so-called "Homelands" within the Republic of South Africa have been portrayed in maps as if they were independent of South Africa. We wish to emphasize that no government, other than the apartheid regime of South Africa itself, has ever recognized the independence of these territories. An application of the normal color scheme for showing independence to the boundaries of these territories has the lamentable effect of misleading non-specialist teachers, students, and the public in general. We urge map publishers to devise a method of accurate representation which would not give credence to the principles of South Africa's racialist policy.

Second, the Western Sahara is often portrayed in maps as if it were a possession of the Kingdom of Morocco. Moroccan claims to this country have been repudiated by the International Court of Justice, the United Nations, and the Organization of African Unity. It is widely and reliably reported that some eighty percent of the country is actually controlled by forces of the Sahrawi Arab Democratic Republic. It is surely misleading to portray this territory as if it were an integral part of Morocco.

The African Studies Association is a nonpolitical, professional, and scholarly membership organization. In this matter, our sole concern is the truthful and accurate representation of geographical and political realities in Africa. The information contained in standard maps passes quickly into textbooks, newspaper articles, and other forms of mass communication. The South African and Saharan situations have resulted 
in portrayals which create serious misconceptions. We shall inform our members of your response to our concern.

Sincerely yours,

Richard L. Sklar

Ed. Note: The above letter was sent to 22 Map Companies. The following response was received from the American Map Corporation:

Dear Mr. Sklar,

We are in receipt of your letter dated 10 November 1981 in which you solicit response to the issue of 'sovereignty' as it relates to two areas in Africa: Western Sahara and South Africa. Our research department maintains a file on all nations of the world and our sources are: The individual countries themselves through the various ministries and departments, the Embassies, Consulates, and UN Missions; the United Nations; The United States State Department and various other published sources.

Western Sahara: Our research department has been following the issue of soverign rule for the past 6 years. We have shown the development of changing interpolitical relationships but still maintain Western Sahara, formerly Spanish Sahara, as an independent entity, and will continue to do so until the situation officially changes.

South African Home States: Several years. ago Transkei, the first of the home state designations, was incorporated into the delineation of South Africa. This was based on published material identifying Transkei as a New Idenpendent Nation. Since that time, there has been clarification on the 'home state status. The only map published by us which delineates the home status is the map of the Republic of South Africa.

One point that I would like to make is that most publishers of textbooks, magazines \& newspapers, as well as other communications media specialists, generally prepare their text materials from sources other than cartographic publications. Often the maps used as illustrations for these publications are prepared by graphic artists - not cartographers, who, by the way are very meticulous about research and reference sources they use.

Another important fact to be remembered is that we often publish a map with up-tothe minute changes, and as soon as it is on press being printed, a change occurs. These changes cannot be incorporated into that edition of the map but must be picked up on subsequent printings, which may be anywhere from 6 months to 1 year later.

I trust that I have provided you with answers to your quiries. Should there be anything further we can do for you, please do not'hesitate to contact us.

Very truly yours,

AMERICAN MAP CORPORATION

Bernice B. Cousins, Director

Cartographic Services

Re: Fulbright and Foreign Visitors . . .

Mailgram: 10/29/81

Senator Alan Cranston, U.S. Senate, Washington DC 20510 